\title{
Phytoestrogens, endocrine disrupters from food
}

\author{
C. Bennetau-Pelissero ${ }^{*}$, K. Latonnelle ${ }^{1,2}$, A. Séqueira ${ }^{2}$ and V. Lamothe ${ }^{1}$ \\ ${ }^{1}$ ENITA de Bordeaux, Micronutrients, Reproduction and Health Unit. 1, cours du Général de Gaulle, BP 201, \\ 33175 Gradignan Cedex, France \\ ${ }^{2}$ Fish Reproductive Biology Laboratory, Université Bordeaux I, Avenue des Facultés, 33405 Talence cedex, France
}

\begin{abstract}
Phytoestrogens are estrogens present in various plants some of which enter human consumption. They belong to different chemical family such as isoflavone, coumestane, resorcilic acid lactones, stylbens and lignans. In plants as in animal fluids they are encountered as conjugated forms. In plants they are found as glycosides, malonyles or acetyles when in animal fluids they are present as glucuronide or sulfate derivatives. They are present in great amount in all soy by products. They are known to interact at different steps of the estrogen pathway including the target cells and the estrogen receptor level. They also act at different steps of the estrogen cycle. They were demonstrated to disrupt the reproductive process in various mammalian species and to interfere with the estrogen cycle in women. They could also be responsible for positive effect such as protection against cancer or cardiovascular diseases. An objective point is made on literature data in order to highlight potential beneficial or adverse effects.
\end{abstract}

\section{Chemical nature of phytoestrogens}

Phytoestrogens are all polyphenols. They belong to different chemical families such as isoflavones, coumestanes, lignans, resorcilic acid lactone and stilbens (see Fig. 1). Their activity is related to at least one phenol group which can be superimposed to that of estradiol [1] (Fig. 1). In addition the most potent compounds also possess a second hydroxyl group on the opposite side of the molecule [2] forming an angle of twist with the first one which mimics that of estradiol. In plants they are usually present as glycoside, acetyl or malonyl derivatives [3] which are more soluble in water than the parent compounds (see Fig. 2). The malonyl forms are predominant is soy and they are stored in cell's vacuoles [4]. In animal fluids such as urine or plasma they are present as glucuronic or sulfate derivatives (Fig. 2) and in that case the consequence on water solubility is the same [5]. This point has to be taken into account when extraction procedure are considered. Indeed, it is needed to proceed to a deconjugation prior to organic extraction. Classically, the deconjugation is performed in acetate buffer ( $\mathrm{pH} 5$ ) using $\beta$ glucuronidase as enzyme [6]. Some of the best extraction solvents for the aglucones are ethanol, methanol or acid ethyl acetate [7].

\section{Phytoestrogen amounts in plants and food}

Phytoestrogens have been studied extensively since the 1950's and all quantification techniques have been used since then. In the early times the only technique available was TLC with poor sensitivity [8]. It was essentially used to analyse clover contents since in some particular clover strain genistein reached up to $3.5 \%$ of dry mater (Trifolium subterraneum dwalganup) [8]. In the early 1980's GCMS techniques were developed in order to measure phytoestrogen content in plants as well as in human and animal urine [6]. The concentrations appeared to be of 100 to 10000 nmole excreted a day [9]. The HPLC techniques were developed associated or not to mass spectrometry [10]. More recently immunological technique were developed at least for a few compounds $[11,12,13]$.

Phytoestrogen content in plants was shown to vary with many factors including the plant genotype [14]. American soy variety are richer than the Japanese one [15]. In addition precocious variety present less isoflavones than latest [16]. The isoflavone content in soy seems also positively correlated to their resistance to pests [17]. Finally, the culture conditions influence the isoflavone content in the plant and especially temperature, rain fall and fertilisers $[16,18]$.

For isoflavones the main sources are clover, soy, heather, alfalfa, chick peas $[9,19,20]$. For lignans the main sources are wheat bran, linseed, grains, red wines [21]. Coumestanes are essentially present in soy sprout, alfalfa, green beans, red beans, split beans, cow peas [9]. Resorcilic acid lactones are micotoxines which are present following a fungi attack on corn, wheat, sesame, barley, oats, rye or peas [9]. Stilbens and particularly resveratrol is present in red wine following botritis attack [22].

In food, isoflavones have been shown to be present in all soy by products, in chick peas [23], in fruits (cherry for example) [9]. Lignans are present in all bran by products [24], stilben in wine [25] and oestrogenic compounds have also been suspected in other beverages like bourbon [26]. In soy by products high concentrations of mainly genistein and 
Isoflavones<smiles>O=c1c(-c2ccc(O)cc2)coc2cc(O)cc(O)c12</smiles>

Micotoxine<smiles>[Z][C@H](O)c1cc(O)cc(O)c1C(=O)OC(=O)CCCCC(O)CCCCC</smiles>

Coumestane

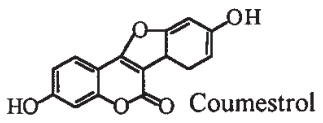

2A

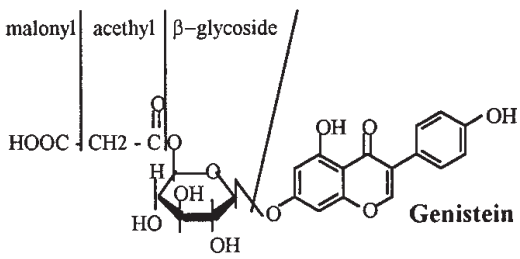

2B

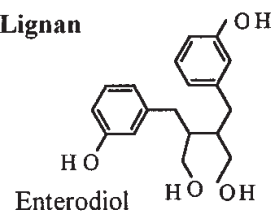

Steroid

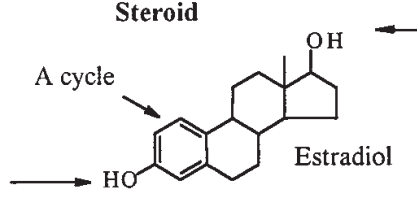

Figure 1. Chemical structure of the main phytoestrogens from Human and animal food.

daidzein under conjugated forms were recorded by Anderson and Wolf [27] with levels of about $2 \mathrm{mg} / \mathrm{g}$ in instant drink. The malonyl forms are the most frequent $[28,29,15]$. The acetyl form of isoflavones apparently appear after heat treatment $[30,29]$. Soy by product can be classified in three categories: the non fermented food, the fermented food and the food containing soy protein extract. Tonyu or tofu are non fermented product and usually contain high levels of genistein and daidzein [27]. In our laboratory, measures performed on tonyu (classical soy milk), exhibited levels up to $220 \mathrm{mg} / \mathrm{L}$ of genistein and daidzein. This mean that a bowl of tonyu will bring to a consumer about $60 \mathrm{mg}$ of genistein and daidzein. This is close to the amount of isoflavones prescribed for menopausal women (Promensil: $45 \mathrm{mg} / \mathrm{day}$; Soylife: $70 \mathrm{mg} /$ day; Evestrel: $75 \mathrm{mg} /$ day; Phytosoya: $35 \mathrm{mg} /$ day) [31,32] and higher than the amount known to lengthen oestrous cycle in women [33] (45 mg/day). Among the fermented soy food four main foods can be identified: nato, miso, tempeh and yoghurts. In these food the percentage of aglucone forms raise since during the fermentation process, bacteria cleave the conjugates. Isoflavone concentrations were given by Anderson and Wolf [27] in these food they were $0.647 \mathrm{mg} / \mathrm{g}, 0.865 \mathrm{mg} / \mathrm{g}$ and $0.282 \mathrm{mg} / \mathrm{g}$ for miso, tempeh and yoghurt respectively. In our laboratory measurements made on soy yoghurts showed levels of $82.20 \mathrm{mg} / \mathrm{L}$ of isoflavones. This is also $10.54 \mathrm{mg}$ of genistein, daidzein and equol per yoghurt. This time again a consumer eating three yoghurts a day is exposed to a dose of phytoestrogens close to that prescribed to a menopausal

women following an estrogen substitutive treatment. In tofu, we managed to find $48,46.16$ and $1.11 \mu \mathrm{g} / \mathrm{g}$ of genistein, daidzein and equol respectively. Among food prepared from soy protein extract the most interesting are the soy based infant formulas. Levels up to $47 \mathrm{mg} / \mathrm{L}$ were found by Setchell [34] in American trade marks. Levels up to $136 \mathrm{mg} / \mathrm{kg}$ of crude powder were found by Irvin et al. [35] in New Zealand trade marks. In our laboratory levels from 17.40 to $26.50 \mathrm{mg} / \mathrm{L}$ were found in French trade marks. This corresponds to a daily intake of $14.83 \mathrm{mg} /$ day to $18.03 \mathrm{mg} /$ day for a baby between 0 to 2 weeks. It is important to note that in all cases authors agree to say that, pondered to the body weight, these concentrations lead to daily intakes 7 to 11 times higher than the classical estrogen substitutive treatment in menopausal women.

However, according to Setchell, [36] the main soy by product found in food from western countries are oil and lecithin which are low in phytoestrogens since isoflavone migrate with protein during lecithin preparation. Indeed, in our laboratory we managed to assay both daidzein and genistein, in soy lecithin sold for direct human consumption. The levels were higher for daidzein than for genistein i.e. $2.4 \mu \mathrm{g} / \mathrm{g}$ and $0.86 \mu \mathrm{g} / \mathrm{g}$ respectively. The average daily intake is thus likely to be low i.e. $<1 \mathrm{mg}$ a day. However, food habits are changing in our western countries and soy products are increasingly advertised for their properties on cholesterol lowering. Nowadays no real study was undertaken to assess clearly the human exposure of a given population. This is of interest considering substitutive estrogenic 
treatments involving isoflavones which added to regular soy intake may lead to over loading. Indeed, measurements presented by Setchell [36] show that isoflavone plasma levels can be 10000 to 100000 times higher than estradiol plasma concentration along estrogenic cycle. With such levels, it is possible to consider physiological effects of phytoestrogens.

Beside isoflavones other estrogenic compounds were also identified in other protein sources. For example in protein extracts from alfalfa Knuckles et al. [37] found levels between 8 to $37 \mathrm{mg}$ of coumestrol $/ \mathrm{kg}$.

\section{Phytoestrogen in human and animal fluids}

In animals various metabolic reactions occur after ingestion. Some of them are performed into the gut some occur in the liver. First, deconjugation seems to occur due to the action of the gut microflora [38]. However, this deconjugation also occurs in fish where the bacterial microflora is known to be nearly ineffective [39]. This rises the question, at least in this model, of another process maybe involving the stomach and its low $\mathrm{pH}$ which can play a part in the deconjugation process. Some of the metabolic processes tend to reinforce the estrogenic effect of the compounds. In the isoflavone family, transformations are conducted by the gut microflora such as the transformation of biochanin A into genistein or of formononetin into daidzein (Fig. 3) [40,41,42]. They are also responsible for lignans bio-transformations from matairesinol and seccocisolariciresinol into enterodiol and enterolactone and consequently in the bioavailability of both isoflavones and lignans $[43,44]$. It can vary greatly from an animal to another ruminant or not. In sheep for example metabolisation of biochanin A into genistein and formononetin into daidzein and equol under free and conjugated form was demonstrated [45], when in hen injection of formononetin leads to daidzein and equol under the sulfate form [46]. It seems that gut absorption is influenced by gut microflora which in turn is influenced by diet habits and thus differences can be noted even between two persons eating the same diet [47]. For example a diet rich in carbohydrates leads to a higher production of equol than a diet low carbohydrates [48]. Biochanin A and formononetin are the isoflavones from chick peas or clover $[23,49]$. They are not, or very weakly estrogenic, when daidzein seems to be at least 10 times more active than formononetin and genistein 10 times more estrogenic than biochanin A [50,51,52]. Moreover, in monogastrics such as rats or humans daidzein, present in soy, is also metabolised into equol by the mammalian gut microflora $[9,53,54]$. This time again, equol is 100 times more estrogenic than daidzein. In the lignans family, the compounds occurring naturally in the plants i.e. seccoisolariciresinol and mataïresinol are not estrogenic at all [44]. Their transformation occurs in the gut of primates (monkeys and humans) and lead to the estrogenic compounds enterolactone and enterodiol [21]. Hence, the circulating forms may be different from the ingested one first because of metabolisation in the gut and secondly because
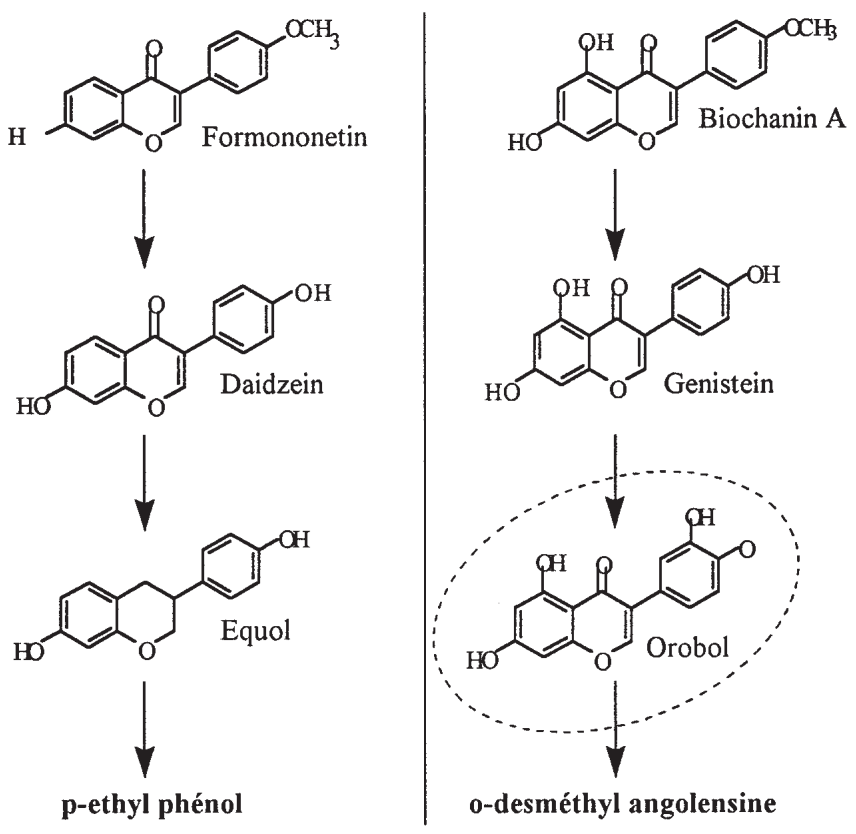

Figure 3. Main metabolic pathway in the isoflavone family.

of conjugation to sulfate or glucuronic acid which occurs in the liver after the absorption process [55].

Measurements in animal or human urine were performed since the early 1980's. Axelson et al. [56] measured equol urine levels excreted a day between $10.7 \mu \mathrm{g}$ and $43.3 \mu \mathrm{g}$ in humans of different sex and different ages. Adlercreutz et al. [54] also measured lignans concentrations in women urine as the concentrations excreted by 24 hours and found levels from 1.04 to $3.18 \mu$ moles depending on the diet (vegetarian or omnivorous) or the health status (with or without breast cancer). Setchell [48] note that mean plasma isoflavone levels in women under $50 \mathrm{mg} /$ day isoflavone, range between 80 and $800 \mathrm{ng} / \mathrm{mL}$. Bioavailability studies shown that genistein and daidzein half life in women plasma after a unique intake of isoflavone is about $7.9 \mathrm{~h} \mathrm{[48].} \mathrm{In} \mathrm{addition,} \mathrm{a} 50 \mathrm{mg}$ intake lead to a pick of isoflavone between 110 to $750 \mathrm{ng} / \mathrm{mL}$ approximately, 5 to 6 hours after ingestion. According to our results, in rats, treatments with $10 \mu \mathrm{g} / \mathrm{g}$ BW of daidzein lead to $74 \pm 11 \mathrm{ng} / \mathrm{ml}$ of plasma daidzein and $68 \pm 13 \mathrm{ng} / \mathrm{ml}$ of plasma equol. These levels are 1,000 to 10,000 times higher than the endogenous estrogen levels depending on the moment of the cycle which is considered. Because, up to now, the sensitivities of the measurement techniques were not sufficient it was difficult to assay these compounds in plasma and to correlate circulating concentrations to physiological effect. Nowadays, immunological assay such as RIA [11] or ELISA [12,13] seem very promising and will open this investigation field. 


\section{Physiological effects in vivo in plants and animals}

\section{In plants}

Phytoestrogens in plants may play important roles. It has been suggested that they can be pigment precursors [57], lignification agents, or excretion products [58]. In leguminous it was demonstrated recently that isoflavones is mainly produced in the young plant by the apex of the roots [59]. It seems also that it is an attractive compound for symbiotic micro-organisms such as Bradyrhysobium japonicus living with Glycine max (soy) [60]. These micro-organisms allow the plant to use the atmospheric nitrogen and imply lower nitrogen fertilisation. In certain plant from the genus citrus, phytoestrogens concentrations rises during the reproductive process [61]. Several authors thus suggest that they are implied in this function. In several occasion, the phytoalexin effect of phytoestrogens i.e. they protective effect against pests or parasites, was suggested. It is the case for coumestrol in alfalfa [62], for resveratrol in grapefruits [22], for biochanin A and formononetin for clover [63] and genistein and daidzein for soy [9].

\section{In animals}

Several effects can be cited in relation to the oestrous cycle in female (Fig. 4). In mammals the most important disruption was observed in ewes grazing clover pasture in Australia [64]. In that case females were exposed to biochanin $\mathrm{A}$ and formononetin but as mentioned earlier, these compounds were subsequently metabolised into daidzein, and genistein two phytoestrogens which are also present in soy and then into equol [9]. The clover disease, as it was called in the early 1960's, can then be considered as a potentially sharp disruption of the reproductive function induced by phytoestrogens from other sources. Basically, phytoestrogens were observed to inhibit the hypothalamic LHRH secretion [65] and as a consequence the LH one [66]. Because LH synthesised by the pituitary acts on the ovulating process, it was understood that the anovulatory syndrome observed on ewes grazing clover rich in phytoestrogens may come from this effect. It has now been observed that genistein the phytoestrogen obtained from biochanin A is able to inhibit the protein kinase $\mathrm{C}$ action [67] which is known to be involved into LHRH release [68]. Moreover, it has recently been shown that genistein also inhibited GABAA stimulation of LHRH cells [69]. This is then

\begin{tabular}{|ll|}
\hline LHRH : Lutheotrophic hormone releasing hormone \\
LH : Luteotrophic hormone & FSH : Folliculostimulating hormone \\
$\boldsymbol{P}:$ Progesterone & E2 : Oestradiol
\end{tabular}

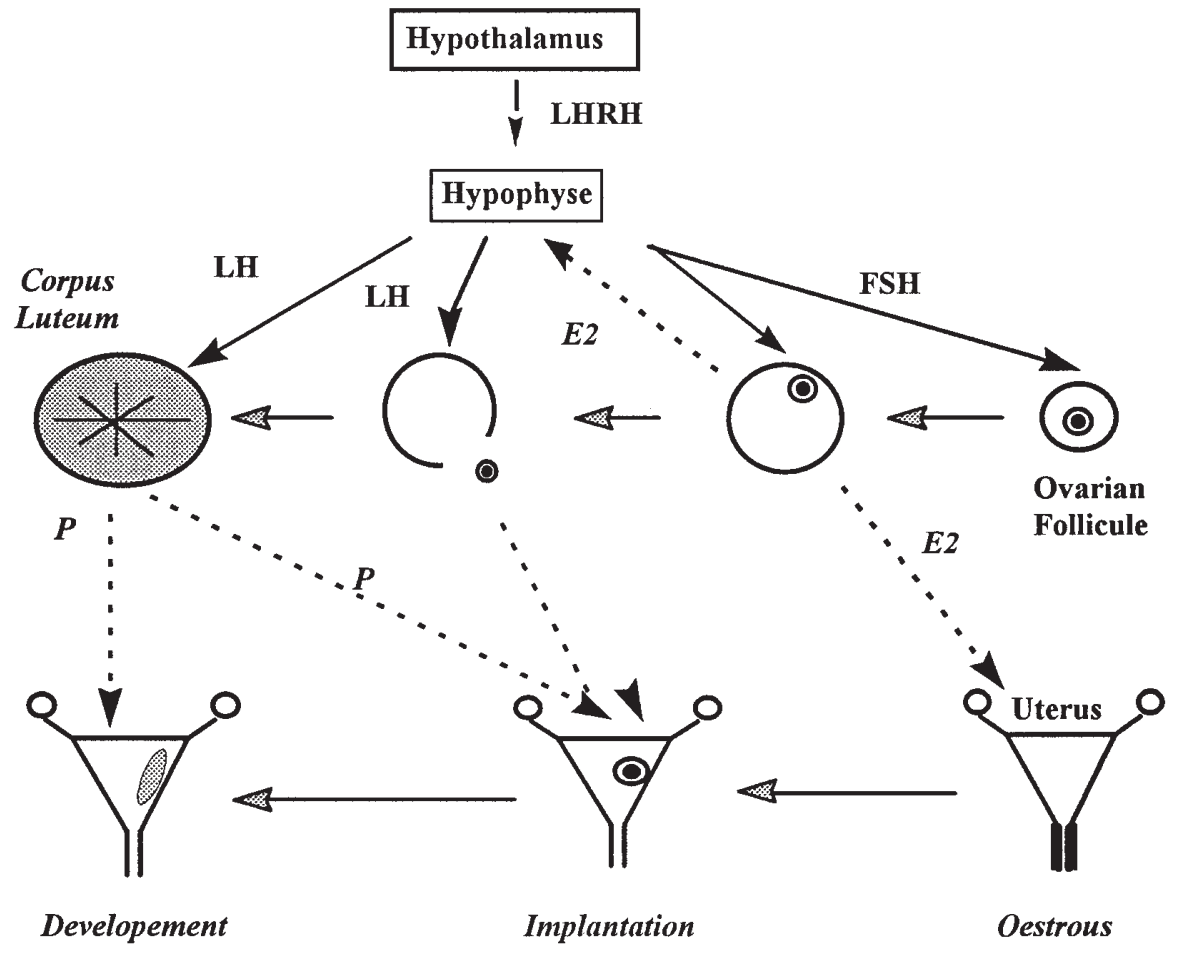

Figure 4. Main different steps of the oestrous cycle in mammals.

ANALUSIS, 2000, 28, $N^{\circ} 9$

(c) EDP Sciences, Wiley-VCH 2000 
another information in favour of a central inhibition of reproduction in animal.

Because LH is also involved into progesterone secretion by the corpus lutheum resulting from the ovulated follicle, this can be the way by which phytoestrogen inhibit progesterone production [70]. This inhibition is probably responsible for the high abortion rate observed in ewes exposed to estrogenic pasture [59,71].

At last because of estrogenic effect, phytoestrogens were responsible for permanent oestrous in mammalian females exposed to them $[59,72]$. They were also responsible for vagina hypersecretion which characterise contaminated females and which impairs sperm progression into the female reproductive tract [59].

In male only little data are available. They were obtained especially on isoflavones and coumestanes. About the clover disease, a few studies reported feminisation of males such has growth of teats and "milk" secretion by immature or castrated males $[59,64]$. In adult males only one study reported a decrease of sperm count and a raise of the abnormal sperm count [73]. Works by Whitten and collaborators, explored the effect of coumestrol at concentrations compatible with diet contents on embryo development and neonatal phase in rats $[72,74,75,76]$. She demonstrated that coumestrol induced abnormal development in both males and females exposed in utero like cryptorchydism in males and decrease of ano-genital distances in females. Puberty was reached earlier in females. Perturbation of sex behaviour (delay in mating receptive females) was observed in males exposed neonatally to coumestrol. Indeed, the coumestrol exposure increased the delay between contact and mating. The isoflavones were essentially studied by Hughes Jr's group. They worked on prenatal exposure [77], neonatal exposure [78] and adult exposure [79]. In rats, they shown that heavy exposure of mother $(25 \mathrm{mg} / \mathrm{female})$ lead to lighter pups, decreased ano-genital distances and perturbation in puberty apparition. With $5 \mathrm{mg}$ genistein/female, puberty is delayed in daughter exposed in utero. Neonatal exposure was carried out using lower amounts of genistein. $10 \mu \mathrm{g}$ injection on new-born rats lead to an increased LH surge in response to $\mathrm{GnRH}$ stimulation. However, with doses from $50 \mu \mathrm{g}$ to $1000 \mu \mathrm{g}$ the LH surge obtained in response to GnRH stimulation is decreased. According to the authors, this type of doses could be responsible for a delay in puberty and could lead at the extreme to anovulatory syndromes. In adults, the same pattern is observed with either low doses of genistein (10 ng/kg BW) and high doses $(10 \mu \mathrm{g} / \mathrm{kg} \mathrm{BW})$. In males, no effect of neonatal exposure was reported so far.

Still in animals, tests were performed on the putative cancer protection of phytoestrogens. Experiments were designed on chemically induced breast cancer in vivo [80]. The protection is evident especially when phytoestrogens are used in a preventive way $[81,82]$. However, the concentrations used are usually high since the animal model were exclusively fed with soy products and of the same order than those known to induce estrogenic responses.
Other effects were tested based on human epidemiological studies showing that Asian diets may be responsible for lower incidence of cardiovascular diseases. It was shown then that the substitution of animal protein by soy protein in a rat diet lead to the reduction of both serum and LDL cholesterol [83]. However, it is not clear from these substitution experiment if the effect is due essentially to compounds present in soy or to the fact that soy protein itself contains no cholesterol. To add to the confusion, several studies performed on animal using casein with pure isoflavonic compounds failed to produce the cholesterol lowering obtained with soy with the same amount of phytoestrogens [48]. In our laboratory, we failed to show any genistein effect on circulating cholesterol when diet differing only on their genistein content were given to fish [submitted paper].

\section{In vitro effects}

In vitro studies demonstrated in different species including fish, rodent and human showed that, at least, some phytoestrogens from the isoflavone family were able to inhibit aromatase. This enzyme is one of the key enzyme of the metabolism of estradiol. It allows the transformation of $\Delta_{4}$ androstenedione into estradiol. It is expressed in fish ovary and in the uterus of mammal $[84,85]$.

Still in vitro, phytoestrogens from the isoflavone family as well as coumestrol in a few cases were demonstrated to bind to the estradiol binding protein present in plasma. These kind of studies were performed with fish SBP [86] and with Human SHBG [87,88] and $\alpha$ Feto-Protein [89]. In humans genistein was also shown in vitro to induce SHBG synthesis by the liver [90].

Many enzymes seem to be affected by at least some phytoestrogens. Tyrosine kinase (TK) and Protein Kinase C (PKC) inhibition were demonstrated for at least some of the isoflavonic compounds [91,67]. A few years ago already, Markovitz et al. demonstrated that genistein was an inhibitor of DNA Topoisomerase II [92]. This enzyme is implicated into certain gene transcription process. Some other enzymes implicated in the reproductive process like Prostaglandin $\mathrm{H}$ synthase was shown to be inhibited by genistein [93]. In addition, cholesterol-7- $\alpha$-hydroxylase, an enzyme implicated into primary biliary acid formation from cholesterol in colon was also demonstrated to be inhibited by lignans [94].

\section{What is known about the estrogenic effect at the target cell level}

Estrogen receptor belongs to the steroid receptor family with retinoic acid [95]. They are proteins which have been shown to present 6 different regions (see Fig. 5). The A/B region is implicated in the process of dimerisation of the receptor. 
$5 \mathbf{A}$

\begin{tabular}{|c|c|c|c|}
\hline \multirow{2}{*}{ ER } & \multicolumn{2}{|c|}{ DBD } & LBD \\
\hline & & & \\
\hline Transactivation & & & \\
\hline functions & $\overline{\mathrm{AF}}$ & & $\mathrm{AF} 2$ \\
\hline
\end{tabular}

5B

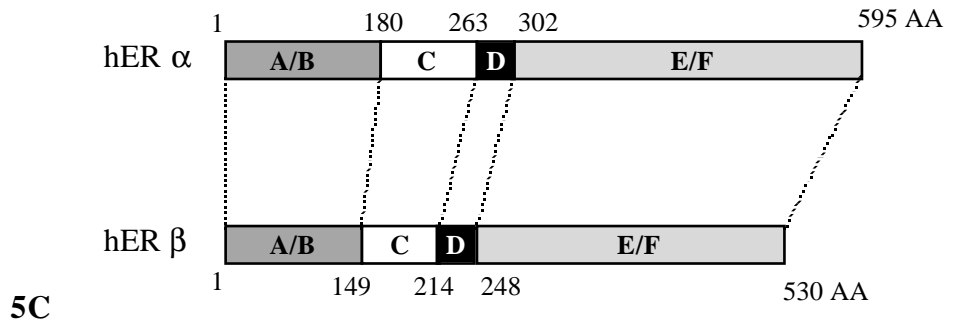

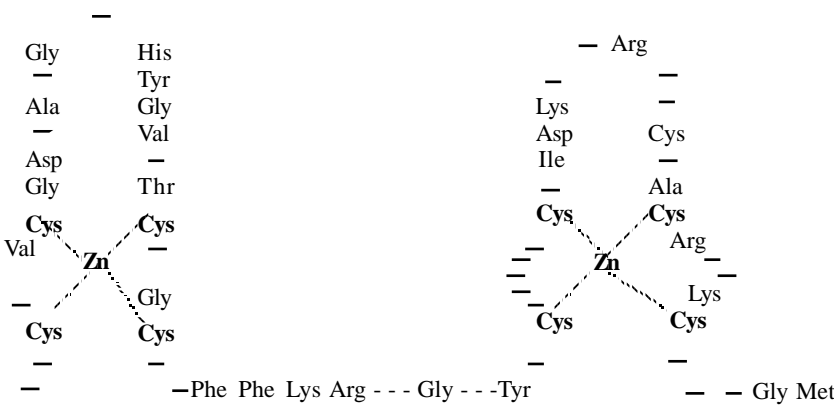

Figure 5. Characteristics of estradiol receptor (ER). 5A: general structure of the ER. 5B: comparison between ER $\alpha$ and ER $\beta$. 5C: zinc finger structure of the DNA binding domain.

The $\mathrm{C}$ region is implicated into the DNA binding. It forms two zinc fingers and is called DNA Binding Domain. The E/F region includes $12 \alpha$ helices and forms the ligand binding domain LBD [89]. Within the A/B region there is a first transactivation function named AF1. This transactivation function interacts with the LBD to enhance the estrogen action on the transcription of estrogen dependant gene. However, the A region regulates the AF1 function since, when it is deleted, the estrogen dependant genes can be induced without ligand. For that reason the AF1 transactivation function is considered as ligand independent. Another transactivation function named AF2 has also been identified in the F region. These receptors act directly at the DNA level on a specific estrogen responsive element ERE which is a palindromic sequence AGGTCAnnnTGACCT. It should be noted however that the ERE may vary from one target cell type to another. In that case the palindromic sequence is the same but the number of bases between these two sequences may be different as shown for the ERE of the vitellogenin gene and that of LH hormone in pituitary cells [96]. These are palindromic sequences on which a dimmer form of two estradiol receptors binds. The dimerisation needs either the presence of specific ligand (estrogens) or phosphorylation at specific sites encountered on the A/B domain [97]. It has been demonstrated that the ER phosphorylation is essential for both dimerisation and gene transcription [97]. This phosphorylation is performed at 8 specific sites present on the $\mathrm{A} / \mathrm{B}$ and $\mathrm{C} / \mathrm{D}$ region and one additional site present in the ligand binding domain $(\mathrm{E} / \mathrm{F})$. The first sites are serine residues numbered Ser ${ }^{104,106,118,154,167}$ (on A/B region) and Ser $^{236,294,305}$ which are the target of different kinase such as MAP Kinase (MAP), Protein Kinase C (PKC), and Protein Kinase A [98]. The last site is $\mathrm{Tyr}^{537}$ in the EF region which is the target of Tyrosine kinase $[99,100]$. Among all these phosphorylation sites, $\operatorname{Ser}^{118}$ phosphorylated by MAPK [101] seems to be one important site implicated in the ligand binding with or without the co-operation of other sites. Ser ${ }^{167}$ is implicated in DNA binding according to Arnold et al. [102]. $\mathrm{Ser}^{236}$ and $\mathrm{Tyr}^{537}$ are both important for dimerisation process of the receptor $[97,103]$. 
Two forms of the estrogen receptor have been identified in mammals and particularly in rodent and Human. They are called Er $\alpha$ and $\operatorname{Er} \beta$ [104] (Fig. 5b). They were not identified in the same proportion in all tissues tested and some tissues were shown to exhibit a great proportion of the $\alpha$ form when others a great proportion of the $\beta$ form $[48,105]$. Namely, $\mathrm{ER} \beta$ is predominant in human brain, thymus, bladder, prostate, lung and bones. ER $\alpha$ is predominant in testes, kidney and adrenal. Both forms were identified in blood vessels, woman breast, uterus and ovary. These two forms derive from two specific genes and present more or less the same six regions [106] (Fig. 5b). The main differences were observed in the $\mathrm{E} / \mathrm{F}$ region. This could explain why binding of these two forms to estrogenic chemicals is not always the same. Nowadays, different forms of the $\alpha$ and the $\beta$ receptors are reported in the literature $[107,108]$. They are usually truncated forms obtained by natural splicing.

Works on Xenopus laevis and MCF7 cells shown that the receptor binding to the DNA binding domain is linked to a cascade of reaction implicating different cis and trans promoters and inhibitors [109]. They vary with target cell-type. The cis domains were generally identified between the ERE and the estrogen dependant gene like NF1 or AP1 [110,111]. Some cis domains interact with specific trans factors like AP1 and trans AP1. Some of the trans factors interact either directly with the receptor (RIPs: Receptor Interacting Proteins) or with the component of the basic transcriptional unit. They are coactivators such as TIF-1 (Transcription Intermediary Factor-1), SRC-1 (Steroid Receptor Coactivator 1) or Sp1 [112,113,114], or corepressors like SMRT, RIP 140 [115]. Some of these trans activators or inhibitors may also be kinases like TIF1 $\alpha$ [116]. This control of the estrogen dependant gene seems then to be a balance between several coactivators and corepressors which are not the same from one cell line to another. This is schematically summarised in figure 4 adapted from Wiegel [97]. Then is at been suggested by recent experiments that several estrogenic chemicals may induce estrogen dependent genes without an interaction with ER and hence with the ERE [117]. For example is has been shown that EGF treatment of ovariectomized mice resulted in ER translocation and phosphorylation in uterine cells. In addition, rat uterine ERs can be stimulated by cAMP, EGF and IGF1 [118,119]. In addition activation by dopamine or melatonin were reported [120,121].

\section{What is known about possible interactions of phytoestrogens at the target cell level}

Not all phytoestrogens from the different family listed above were tested so far. It is likely that they do not exhibit the same interactions with the estrogen dependant gene machinery. Estradiol receptor binding was one of the first investigation conducted with phytoestrogens especially those of the isoflavone and coumestane family [122]. These tests showed that these compounds could compete with estradiol for its receptor. However, the type of interaction is not completely elucidate. Indeed, the competition can result from a non specific binding inducing a conformational change of the molecule. The conformational change can then lead to a modification of the LBD and therefore can prevent $\mathrm{E}_{2}$ binding. These binding experiment have then to be considered cautiously.

Depending to the model used the affinity of the receptors to phytoestrogens was not always the same. Estrogenicity scales obtained on rodent ER binding exhibited for example for the isoflavone family coumestrol > genistein > daidzein > biochanin A [123]. In ewes, Shutt and Cox [123] found that coumestrol $>$ genistein $>$ equol $>$ daidzein $>$ biochanin $\mathrm{A}=$ formononetin. Recently in our group we observed that the scales were not the same on receptor binding: formononetin $>$ genistein $>$ equol $>$ daidzein $>$ biochanin $\mathrm{A}$ and even vary from trout to sturgeon receptor (data in press).

The discrepancy between animal or tissue model was added to a discrepancy between in vivo and in vitro results. This discrepancy probably came from the different metabolic process occurring on phytoestrogen's way from food to target cells and described earlier in the text. It appears nowadays, that these steps are crucial.

Recently, the discovery of the $\beta$ form of the ER at least explains why all the tissues not react the same to phytoestrogens. Indeed, Kuiper et al. [124] demonstrated in vitro that the $\beta E R$ had a greater affinity for phytoestrogens than the $\alpha$ form. Because, as we previously mentioned, $\alpha$ and $\beta$ forms were not expressed equally in all estrogen target tissues, the discrepancy between tissue effects could be at least partly explained.

Binding to the receptor was tested on many tissues and many models including Human carcinoma cells or fish hepatocytes. In fish, tamoxifen a partial antagonist of estradiol was shown to inhibit at least partially isoflavone estrogenic effect [125]. ICI 182,780 a pure LBD inhibitor not always prevent the estrogenic effect induced by phytoestrogens (personal unpublished results). All these data suggest that binding of phytoestrogens onto the ERE's LBD may not be the only way by which phytoestrogens induce the estrogenic response. When estradiol and phytoestrogens are tested together some author report additive effects [126]. At the cell levels it seems very difficult to observe antagonistic effects. According to Makela et al. [127] if there is an anti-estrogenic effect it may be mediated by another pathway than the ER mediated pathway. The compounds and the concentrations considered are not always the same, and is seems rather difficult for the moment to get a clear opinion at least at the in vitro levels on the agonist or antagonist effect of phytoestrogens in the presence of estradiol.

In addition, as mentioned above, genistein, one phytoestrogen from the isoflavone family was shown to be both a tyrosine kinase (TK) inhibitor and a protein kinase $\mathrm{C}(\mathrm{PKC})$ inhibitor. This suggest complex interactions at the different steps of the estrogen dependant gene regulation pathway. As 


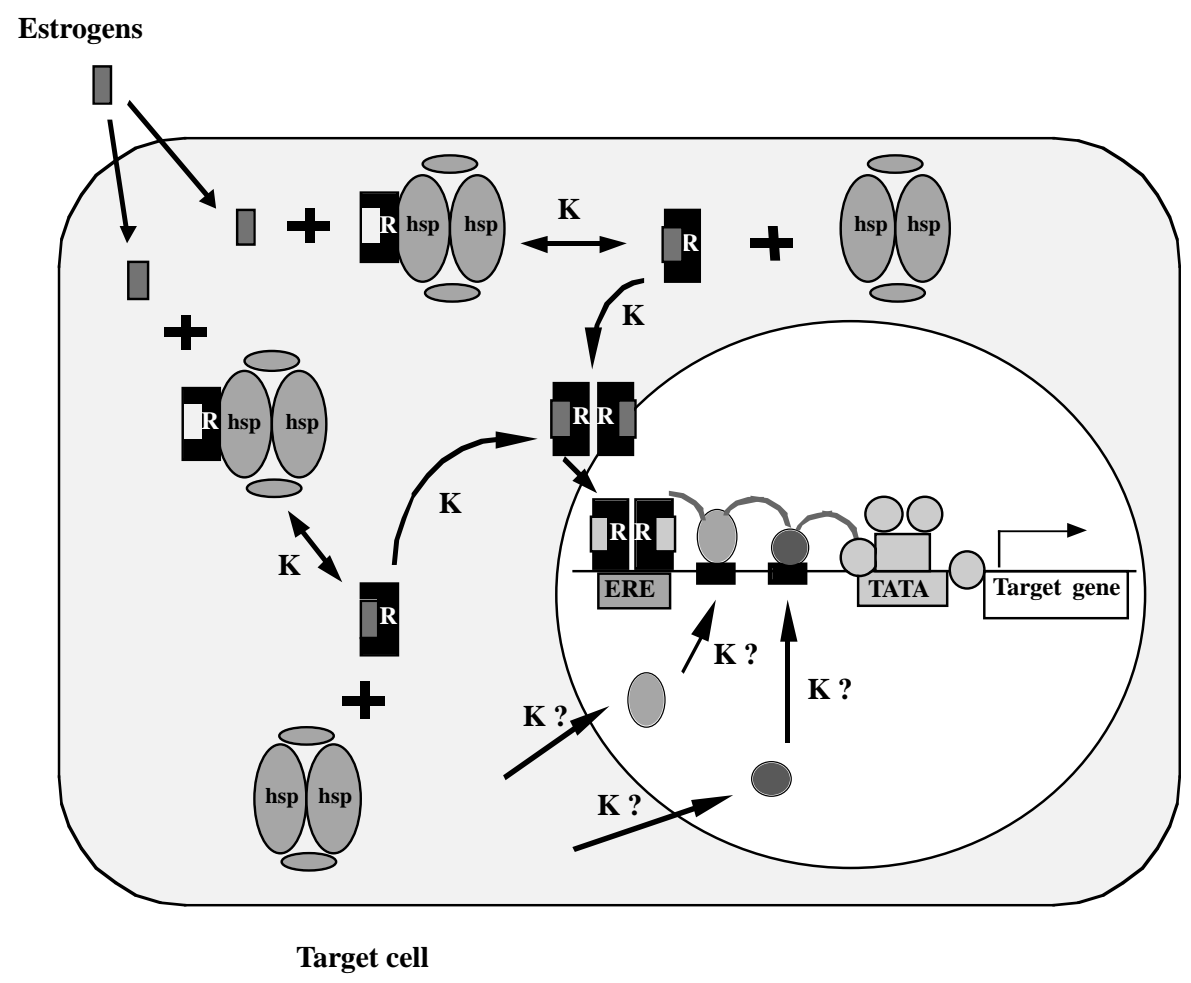

Figure 6. Schematic representation of the control of estrogen dependant genes. ERE: Estrogen Responsive Element, HSP: Heat Shock Protein, K: Kinases, R: Estrogen Receptor, TATA: Tata Box.

far as we know, nothing has been done yet at this levels of the information process.

\section{Effects in humans}

\section{Effects on the reproductive tract}

Up to now, because humans are considered to be exposed only to low doses, effects on the reproductive function have not been considered. However, the women cycle is known to be influenced by doses of $45 \mathrm{mg}$ genistein a day [33]. In that case Cassidy [33] demonstrated that the LH surge was delayed and that the oestrous cycle was longer. This is also observed in Japanese women for whom the oestrous cycle last for 32 days against 28 to 29 days in western countries. This is considered to be due to a high intake of soy and hence of phytoestrogens [128]. It is interesting to note that the longer the oestrous cycle the lower the risk of breast cancer when the reason for this association is still unclear [129]. Still in women but this time after menopause, phytoestrogens were claimed to reduce bone loss, hot flushes and breast cancer acting as other synthetic estrogens in estrogen replacement therapy. Initially this hypothesis was mentioned based on epidemiological studies comparing Asian and Western women [130]. However, it must be kept in mind that phytoestrogens are not the only elements differing between Asian and Western diet. Considering case studies it appears that, for hot flushes reduction, a strong placebo effect can be detected [48]. The estrogenic effect on the vaginal epithelium is still controversial since it seems to depend from operator examination [48]. Moreover, it seems difficult to interpret the different studies in the literature because the design of the trials are not always consistent. Concerning breast cancer, no data are available nowadays about strict effect of isoflavonic phytoestrogens and breast cancer in vivo in women. All hypothesis are actually speculations from data obtained in vivo in animal and described above in the text. However, in vitro the anti-estrogenic effect is not fully understood. Several studies demonstrated a protective effect of soy but not of phytoestrogens themselves. In men, the Asian food was correlated to low incidence of testicular cancer and hypospadia [48]. In addition, the low risk of prostate cancer in Japanese men was correlated with high plasma levels of daidzein and equol, but genistein was not measured [131]. Beside the effects on the reproductive function, other effects were investigates still based on the epidemiological studies performed comparing Asian and Western populations.

As far as we know, no estrogenic effects were ever recorded in men. It is not known if this is because they have not been investigated, if they are masked by other 
compounds from the environment, or because the effects of phytoestrogens do not exist. Considering high food contents, and urine levels obtained in some cases, it could be worth keeping an eye on consumers and may be look for evident consequences of estrogen exposure like decrease of sperm fertility, reduced libido, reduced male secondary characters. In those investigations the main problem, of course, is the multiple exposure to environmental estrogenic chemicals which is now well documented [132].

\section{Effect on cholesterol and cardiovascular diseases}

Like in animals, experiments were designed in order to investigate the effect of phytoestrogens on cardiovascular diseases and cholesterol lowering. In that case, it appears that it is the animal investigation which lead to human investigation [133]. The investigations in that area lead to controversial results. First it appears that a soy protein intake of $60 \mathrm{~g}$ a day provoked a $9.6 \%$ reduction in total cholesterol in healthy premenopausal women $[33,134]$. However, in postmenopausal women the same intake for 4 weeks lead to a rise of $14 \%$ total cholesterol [135]. In addition, it was recently shown that soy milk supplementation in healthy men did not alter serum lipid concentration [136,137]. From all these results taken together with those published in animals it could be say that when soy is used as a substitutive product to other protein source of animal origin then, total plasma cholesterol is often severely reduced. This may be due to the fact that protein from animal source often contain cholesterol when soy does not. However, a slight effect is also measured sometimes when soy is used in supplementation trials. In that case, it may be imagined that ethanol extractable compounds from soy can act on cholesterol metabolism but probably only to a short extend (10\% reduction only). At last, it may be interesting to noticed that according to the review by Anderson et al. [138], the higher the initial level of plasma total cholesterol the stronger the effect of soy. In that case the role of isoflavone seems proved since the effect is strictly correlated with the isoflavone intake. As a summary an alcoholic extraction completely abolish the effect of soy [139]. However this effect remains tiny when it is not due to substitution and is likely not to be sufficient to reduce severe genetically based hypercholesterolemia [48].

Concerning cardiovascular diseases, other properties of isoflavonic compounds may be evoked that could play a preventive role. Antioxidant properties of isoflavonic compounds may allow cardioprotective effects [140]. It has been shown recently on monkey and rats that isoflavones would increase blood vessel dilatation improving blood flow [141]. Resveratrol a weak estrogenic stilben from wine, as genistein in soy, reduce platelet aggregation and trombin reaction probably through the inhibition of growth factor pathways $[142,48]$. In these cases the inhibition of tyrosine kinase or PKC activity may be involved.

\section{Effects on osteoporosis}

Isoflavonic compounds are recognised for their estrogenic effect in human since they are prescribed to menopausal women in estrogen replacement therapy. They were suspected to reduce hot flushes incidence [143] and they are actually suspected to protect against bone losses since this effect was shown is rodents and especially in ovariectomized rats [144]. Additionally, the incidence of osteoporosis is lower in Asia where people eat more soy [145]. Moreover, ER were discovered in osteoblast cells [146] and they were found to be of the $\beta$ type [105]. This conducted several authors to look for blood markers of bone loss such as Dpyrodinoline or N-telopeptide [147]. It was shown that the urinary excretion of these two markers was significantly reduced after a 3 month exposure to $60 \mathrm{mg}$ a day of isolated soy protein. However this study was not conducted using pure phytoestrogens. More recently Potter et al. [148] shown that a 6 month intake of isolated soy protein increase bone mineral content in postmenopausal women when compared to a diet containing casein. This time again, this was not tested using pure compounds.

\section{Phytoestrogens and cancer}

Phytoestrogens are classically considered as cancer inhibitors in humans $[149,150]$ and in animals $[151,152]$. First this opinion proceed from epidemiological observations correlating high soy and isoflavone intakes in Asian countries and low incidence of uterus and breast cancer. A case study reported by Ingram et al. [153] also associated the appearance of breast cancer to low urinary levels of equol, daidzein, enterodiol, enterolactone and mataïresinol. If this study is interesting it cannot be taken as a proof since phytoestrogens may be only a characteristic of a diet habit richer in fruits and legumes. It could then be either the higher fibre intake associated to a lower fat or meat intake which could be really responsible for the lowering of cancer incidence. Nowadays, cautious are taken since it appears that if the low cancer incidence associated to Asian diets disappear with change for Western diet, phytoestrogens are not the only difference between Western and Eastern cookeries. Hawrylewicz et al. [151] suggested that at least in soy "several component in soybean namely protease inhibitors, isoflavones, inositol hexaphosphate, phytosterols and saponins inhibit a variety of tumors in various tissues". They added that "the lower amount of methionin in soy protein compared with casein may be important in selectively retarding the growth of tumors". Beside these considerations it must be reminded that cooking habits are different between Asia and Western countries. Grilled meats are largely consumed in Western countries and they potentially contain carcinogenic compounds such as those obtained from the Maillard's reaction. On the opposite Japanese people are 
very fond of crude fish low in cholesterol and of course without those Maillard's reaction compounds.

Many studies were performed in order to analyse and to explain this protective effect against cancer. Analysis were performed in vivo on animal using chemically induced models of tumor [80,152]. From all these data it appears that anticancer effect can be registered on both estrogen dependent and independent tumor cells and may be the results of different properties of phytoestrogens. They are antioxidants as other polyphenols [140]. They induce apoptosis at least in certain situation and certain cell lines like genistein although at very high concentration $0.15 \mathrm{mM}$ [154] or resveratrol in MCF7 cells [155]. Genistein for example inhibits angiogenesis in vitro in BME cells at concentrations of $10 \mu \mathrm{M}$ [156]. Inhibiting aromatase, phytoestrogens may play a preventing role in estrogen dependant cancers by preventing raise of estradiol plasma concentration [157]. Binding to SBP or SHBG they enter in competition with estradiol and increase the proportion of free and conjugated estradiol and hence its urine elimination [158]. Properties like TK, PKC or DNA topoisomerase II inhibition may explain many anti-cancer effect since these enzyme activities are involved in many intracellular pathways including some implicating tumour growth factors [159].

Tentative explanations were given by performing in vitro tests on cell systems from animals and Humans. The demonstration of antiproliferative effect on estrogen dependant cell lines nowadays, is not clearly done. For example, Le Bail et al. [160] when testing isoflavones on MCF7 and MDA oestrogen independent carcinoma cells did not find an antiestrogenic activity of these compounds. They suggest that the antiestrogenic properties may occur through other receptor independent pathways. In the same way Welshons et al. [161] shown that enterolactone, enterodiol and equol were able to stimulate MCF7 cell growth, enterodiol and enterolactone being antagonised by tamoxifen. Controversially, Peterson and Barnes demonstrated that genistein, daidzein, and biochanin A, all three, inhibited MCF7 and MDA cells proliferation [162] the most potent inhibitor being genistein. In some cases authors report antagonism between estradiol and phytoestrogens explained most of the time by a competition for the ER. For example equol was shown in MCF7 cells to antagonised the effect of estradiol when daidzein did not [163]. In addition, genistein was found in ER(-) and $\mathrm{ER}(+)$ breast cancer cells to have both estrogenic effect and antiproliferative properties when equol was both estrogenic and inducing cell proliferation [164]. Other authors also reported additive effects between estradiol and phytoestrogens [126]. A problem is raised from these results, genistein may be an interesting antiproliferative compounds in vitro however, following soy intake it is accompanied by daidzein and eventually equol which do not exhibit the same antiproliferative properties. Co-treatment studies would have to be undertaken to assess what really occurs and in what concentration range.

As a conclusion, estrogenic effects of phytoestrogens and especially those of the isoflavone and coumestane families are clearly demonstrated. In animals, deleterious effects of very high doses on the reproductive process have been shown undoubtedly. Nowadays, soy is increasingly used in human food for its potential beneficial effects. Moreover, estrogen replacement therapy, cholesterol lowering therapy and cancer prevention lead to additional daily intake through specific tablets. This may lead to overloading and at least lead to reconsider the assertion that Humans are only exposed to low doses of phytoestrogens. Beside, it seems at least curious, that compounds used in estrogen replacement therapy, if their effect is clearly demonstrated, their bioavailability clearly established, could be administrated without any control of the total daily intake. If genistein and daidzein are considered as medicines then the daily intake must be controlled and this means that the isoflavone content in normal food must appear on the labelling. This is the only way for a doctor to be sure that his prescription is strictly followed. The wide variations of isoflavone contents in tablets reflect probably the lack of knowledge on people real daily exposure. Wide studies might then be undertaken to assess the exposure of different Western populations.

Considering the potential beneficial effects of phytoestrogens, the literature only clearly shows effects on the oestrous cycle lengthening in human. About osteoporosis, effects are suspected from data obtained on animal and from the measurements of bone loss plasma indicators. However, this effect is not clearly proved because the only way to do that is to undertake long term treatments. About hot flushes reduction, strong placebo effects were reported. About cholesterol lowering, unexplained discrepancies remain between studies reporting effects of soy in man and other reported no effect at all. On cardiovascular diseases, many phytoestrogens' properties may be evoked to justify a preventive effect. However, studies remain to be done to clearly assess the effect of specific molecules at relevant doses in human. About cancer, epidemiological and case studies would strongly suggest a protective effect of phytoestrogens. However, discrepancies remain in vitro. Additional studies would be required to assess if phytoestrogens only act through the estradiol receptor pathway in estrogen dependant diseases. This could explain certain antiestrogenic activities reported only in certain contexts. Moreover, soy intake leads to the intake of different compounds not all of them presenting antiproliferative effects. Lastly, the case of young babies exposed to extremely high levels of phytoestrogens through soy based infant formulas would have to be considered. When food safety grown to be a major concern, it is difficult to explain that we can tolerate exposure of babies to doses 7 to 11 times higher than that having an effect on oestrous cycle lengthening in women. Because cancer prevention is not yet fully investigated, it cannot be evoked to justify such an exposure.

\section{References}

1. Duax, W. L.; Weeks, C. M. In: Estrogens in the environment. McLachlan J. A., Ed., Elsevier Inc. Pub., 1980, pp 11-31.

2. Majak, W. J. Toxicol. - Toxin Reviews 1992, 11 (1), 1-40. 
3. Kudou, S.; Shimoyamada, M.; Imara, T.; Uchida, T.; Okubo K. Agric. Biol. Chem. 1991, 55, 859-890.

4. Teusch, M.; Forkmann, G. Phytochem. 1987, 26, 2181-2183.

5. Brown, J.P. In: Role of the gut microflora in toxicity and cancer; Rowland, I.R. Ed., San Diego: Academic press,1988, pp 109-144.

6. Axelson, M.; Sjövall, J.; Gustafsson, B. E.; Setchell, K. D. R. J. Endocrinol. 1984, 102, 49-56.

7. Jones, A. E.; Price, K. R.; Fenwick, G. R. J. Sci. Food. Agric. 1989, 46, 357-364.

8. Beck, A. B. Aust. J. Agric. Res. 1964, 15, 223-230.

9. Setchell, K. D. R. In: Estrogens in the environment II; McLachlan, Ed., Elsevier Publ. Inc. 1985, pp 69-85.

10. Setchell, K. D. R.; Welsh, M. B.; Lim, C. K. J. Chromatography 1987, 386, 315-323.

11. Wang, W.; Tanaka, Y.; Han, Z.; Cheng, J. J. Agric. Food. Chem. 1994, 42 (7), 1584-1587.

12. Le Houérou, C.; Bennetau - Pelissero, C.; Lamothe, V.; Le Menn, F.; Babin, P.; Bennetau, B. Tetrahedron 2000, 56, 295301.

13. Bennetau - Pelissero, C.; Le Houérou, C.; Lamothe, V.; Le Menn, F.; Babin, P.; Bennetau, B. J. Agric. Food. Chem. 2000, 48 (3), 305-311.

14. Eldrige, A. C.; Kwolek, F. J. Agric. Food. Chem. 1983, 31, 394-396.

15. Wang, H. J.; Murphy, P. A. J. Agric. Food. Chem. 1994, 41, 1961-1967.

16. Kitamura, K.; Agate, K.; Kichuchi, A.; Kudou, S.; Okubo, K. Jpn. J. Breeding 1991, 41, 651-654.

17. Carrao-Panizzi, M. C.; Kitamura, K. Breeding Sc. 1994, 45, 295-300.

18. Tsukamoto, C.; Shimada, S.; Igita, K.; Kudou, S.; Kokubun, M.; okubo, K.; Kitamura, K. J. Agric. Food. Chem. 1995, 43 (5), 1184-1192.

19. Farnsworth, N. R.; Bingel, A. S.; Cordell, G. A.; Crane, F. A.; Fong H. H. S. J. Pharm. Sci. 1975, 64 (4), 535-598.

20. Farnsworth, N. R; Bingel, A. S.; Cordell, G. A.; Crane, F. A.; Fong H. H. S. J. Pharm. Sci. 1975, 64 (5), 717-754.

21. Axelson, M.; Sjövall, J.; Gustafsson, B. E.; Setchell, K. D. R. Nature 1982, 298, 659-660.

22. Soleas, G.; Diamantis, E. P.; Goldberg D. M. Clin. Biochem. 1997, 30 (2), 91-113.

23. Kessman, H.; Barz, W. Plant Cell. Rep. 1987, 6, 55-59.

24. Adlercreutz, H. Front. Gastrointest. Res. 1988, 14, 165-176.

25. Goldberg, D. M.; Tang, E.; Karumanchiri, A.; Diamantis, E. P.; Soleas, G.; Ng, E. Anal. Chemical. 1996, 68, 1688-1694.

26. Van Thiel, D. H.; Galvao-Teles, A.; Monteiro, E.; Rosenblum, E.; Gavaler, J. S. Alcohol.: Clin. Exp. Res. 1991, 15 (5), 822-823.

27. Anderson, R.L.; Wolf, W. J. J. Nutr. 1995, 125, 581S-588S.

28. Eldridge, A. C. J. Agric. Food Chem. 1982, 30, 353-355.

29. Kudou, S.; Fleury, Y.; Welti, D.; Magnolato, D.; Uchida, T.; Kitamura, K.; Okubo, K. Agric. Biol. Chem. 1991, 55, 2227 2233.

30. Farmakalidis, T. L.; Murphy, P. J. Agric. Food. Chem., 1985, 33, 385-389.

31. Kelly, G.; Husband, A.; Waring, M. Clinical monograph on Promensil; Novogen Ed., 1997.

32. Callem, J.; Dolby V. The Health Benefits of Soy; New Canaan, Connecticut: Keats Publishing Inc, 1996, 48 p.
33. Cassidy, A.; Bingham, S.; Setchell, K. D. R. Am. J. Clin. Nutr. 1994, 60, 333-340.

34. Setchell, K. D. R.; Zimmer-Nechemias, L.; Cai, J.; Heubi, J. E. The Lancet 1997, 350, 23-27.

35. Irvine, C. H. G.; Fitzpatrick, M. G.; Alexander, S. L. P. S. E. B. M. 1998, 217, 247-253.

36. Setchell, K.D.R. Am. J. Clin. Nutr. 1998, 68, 1333S-1346S.

37. Knukles, B. E.; de Fromery, D; Kohler, G. O. J. Agric. Food Chem. 1976, 24 (6), 1177-1180.

38. Adlercreutz, H.; Honja, H.; Higashi, A.; Fotsis, T. Hämälä̈nen, E.; Hasegawa, T.; Okada, H. Am. J. Clin. Nutr. 1991, 54, 1093-1100.

39. Lesel, R. Les communautés bactériennes hébergées par la truite arc-en-ciel Salmo gaidneri Ridcharson, facteur de variations et fonctions. Thèse d'Etat $n^{\circ} 924$, University Bordeaux I, 1987.

40. Braden, A. W. H.; Hart, N. K.; Lamberton, J. A. Aust. J. Agric. Res. 1967, 18, 335-348.

41. Chang, H. H. S.; Robinson, A. R.; Common, R. H. Can. J. Biochem. 1975, 53, 223-230.

42. Davies, H. L.; Hill, J. L. Aust. J. Agric. Res. 1989, 40, $157-$ 163.

43. Borriello, S. P.; Setchell, K. D. R.; Axelson, M.; Lawson, A. M. J. Appl. Bacteriol. 1985, 58, 37-43.

44. Setchell, K. D. R.; Borriello, S. P.; Hulme, P.; Kirk, D. N.; Axelson, M. Am. J. Clin. Nutr. 1984, 40, 569-578.

45. Shutt, D. A.; Weston, R. H.; Hogan, J. P. Aust. J. Agric. Res. 1970, 21, 713-722.

46. Chang, H. H-S.; Robinson, A. R.; Can, A. H-H.; Common, R. H. Can. J. Biochem. 1976, 55, 50-55.

47. Knight, D. C.; Eden, J. A. Obstet. Gynecol. 1996, 87, 897904.

48. Setchell, K. D. R.; Cassidy, A. J. Nutr. 1999, 129, 758S$767 \mathrm{~S}$.

49. Adams, N. R. In: Toxicants of Plant Origin. Volume IV, Phénolics; Cheeke P. R. Ed., Boca Raton Florida, CRC Press Inc., pp 24-51.

50. Verdeal, K.; Brown, R. R.; Richardson, T.; Ryan, D. S. J. N. C. I. 1980, 64 (2), 285-290.

51. Thompson, M. A.; Lasley, B. L.; Rideout, B. A.; Kasman, L. H. Biol. Reprod. 1984, 31, 705-713.

52. Welshon, W. W.; Murphy, C. S.; Koch, R.; Calaf, G.; Jordan, V. C. Breast Cancer Res. Treat. 1987, 10, 169-175.

53. Tang, B. Y.; Adams, N. R. J. Endocr. 1980, 85, 291-297.

54. Adlercreutz, H.; Fotsis, T.; Bannwart, C.; Wähälä, K.; Mäkelä, T.; Brunow, G.; Hase, T. J. Steroid Biochem. 1986, 25(5B), 791-797.

55. Xu, H.; Harris, K. S.; Wang, H. J.; Murphy, P. A.; Hendrich, S. J. Nutr. 1995, 125, 2307-2315.

56. Axelson, M.; Kirk, D. N.; Farrant, R. D.; Cooley, G.; Lawson, A. M.; Setchell, K. D. R. Biochem J. 1982, 201, 353-357.

57. Clevenger, S. Sci. Am. 1964, 210, 84-92.

58. Floss, H. G.; Mothes, U. Phytochemistry. 1966, 5, 161-169.

59. Adams, N. R. Aust. Vet. J. 1990, 67, 197-201.

60. Zhang, F.; Smith, D. L. Plant Physiol. 1995, 108 (3), 961968.

61. Maier, C. G-A.; Chapman, K. D.; Smith, D. W. Plant Science 1995, 109 (1), 31-43.

62. Barbetti, M. J. Aust. J. Exp. Agric. 1995, 35 (2), 209-214. 
63. Cook, R.; Tiller, S. A.; Mizen, K. A.; Edwards, R. J. Plant Physiol. 1995, 146 (3), 348-354.

64. Bennetts, H. W.; Underwood, E. J.; Shier, F. L. Aust. Vet. J. 1946, 22, 2-12.

65. Hughes, C. L. Jr; Kaldas, R.S.; Weisinger, A.S.; McCants, C.E.; Basham, K.B. Reprod. Toxicol. 1991, 5 (2), 127-132.

66. Findlay, J. K.; Buckmaster, J. M.; Chamley, W. A.; Cumming, I. A.; Hearnshaw, H.; Goding, J. R. Neuroendocrinology 1973, 11, 57-66.

67. Osada, H.; Magae, J.; Watanabe, C.; Isono, K. J. Antibiot. 1988, 41, 925-930.

68. Melamed, P.; Rosenfeld, H.; Elizur, A.; Yaron, Z. Comp. Biochem. Physiol. Part C 1998, 119, 325-338.

69. Huang, R. Q.; Fang, M. J.; Dillon, G. H. Brain Res. Mol. Brain Res. 1999, 67, 177-183.

70. Obst, J. M.; Seamark, R. F. J. Reprod. Fert. 1970, 21, 545547.

71. Valderrabano, J. Invest. Agr.: Prod. Sanid. Anim. 1992, 7(2), 115-124.

72. Whitten, P.; Lewis, C.; Russell, E.; Naftolin F. J. Nutr. 1995, 125, 771S-776S.

73. Stob, M. In: Handbook of Naturally Occuring Food Toxicants. Rechcigl Jr M. Ed., Boca Raton Florida: CRC Press Inc, 1983, pp 81-100.

74. Whitten, P. L.; Naftolin F. Steroids 1992, 57 (2) 56-61.

75. Whitten, P. L.; Russell, E.; Naftolin, F. Steroids 1992, 57(3), 98-106.

76. Whitten, P. L.; Lewis, C.; Naftolin, F. Biol. Reprod. 1993, 49(5), 1117-1121.

77. Levy, J. R.; Faber, K. A.; Ayyash, L.; Hughes, C. L. Jr. P. S. E. B. M. 1995, 208, 60-66.

78. Faber, K. A.; Hughes, C. L. Jr. Reprod. Toxicol. 1993, 7, 3539.

79. Hughes, C. L. Jr.; Kaldas, R. S.; Weisinger, A. S.; Mc Cants, C. E.; Basham, K. B. Reprod. Toxicol. 1991, 5, 127-132.

80. Barnes, S. J. Nutr. 1995, 125, 777S-783S.

81. Lamartinière, C. A.; Moore, J. B.; Brown, N. M.; Thompson, R.; Hardin, M. J.; Barnes, S. Carcinogenesis, 1995, 16, 28332840.

82. Murrill, W. B.; Brown, N.; Zhang, J-X.; Manzilillo, P. A.; Barnes, S.; Lamartinière, C. A. Carcinogenesis, 1996, 17, 1451-1457.

83. Sirtori, C. R.; Even, R.; Lovati, M. R. Ann. N. Y. Acad. Sci. 1993, 676, 188-201.

84. Pelissero, C.; Lencowski, M. P.; Chinzi, D.; Davail-Cuisset, B.; Sumpter, J. P.; Fostier, A. J. Steroid. Biochem., Mol. Biol. 1996, 215-223.

85. Adlercreutz, H.; Kockrstedt, K.; Bannwart, C.; Bloigu, S.; Hämälaïnen, E.; Fotsis, T.; Ollus, A. J. Steroid Biochem. Mol. Biol. 1993, 44, 147-153.

86. Bennetau - Pelissero, C.; Kaushik, S.; Sumpter, J.; Fostier, A.; Le Gac, F.; Valotaire, Y.; Davail - Cuisset, B.; Le Menn, F Bull. Fra. Pêche Pisci. 1998, 350-351, 571-583.

87. Martin, P. M.; Horwitz, K. B.; Ryan, D. S.; McGuire, W. L. Endocrinol. 1978, 103(5), 1860-1867.

88. Martin, M.E.; Haourigui, M.; Pelissero, C.; Bennassayag, C.; Nunez, E. Life science 1995, 58 (5), 429-436.

89. Gareau, B.; Valette, G.; Adlercreutz, H.; Wähälä, K.; Mäkelä, T.; Benassayag, C.; Nunez, E. Biochim. Biophys. Acta 1991, 1094, 339-345.

90. Moussavi, Y.; Adlercreutz, H. Steroids 1993, 58, 301 - 304.
91. Huang, R. Q.; Fang, M. J.; Dillon, G. H. Res. Mol. Brain Res. 1999, 67, 177-183.

92. Markovits, J.; Linassier, C.; Fossé, P.; Couprie, J.; Pierre, J.; Jacquemin-Sablon, A.; Saucier, J.M.; Le Pecq, J. B.; Larsen, A. K. Cancer res. 1989, 49, 5111-5117.

93. Degen, G. H. J. Steroid Biochem. 1990, 35, 473-480.

94. Sanghvi, A.; Diven, W. F.; Seltman, H.; Warty, V.; Rizk, M.; Kritchesky, D.; Setchell, K. In: Drugs Affecting Lipid Metabolism, Kritchevsky, D; Paoletti, R; Holmes, W. L. Ed. Plenum Press. 311-322, 1984.

95. Carson - Jurica, M. A.; Schrader, W. T.; O'Malley, B. W. Endocr. Rev. 1990, 11 (2), 201-220.

96. Ashby, J.; Tinwell, H.; Pennie, W.; Brooks, A. N.; Lefevre, P. A.; Beresford, N.; Sumpter, J. P. J. Appl. Toxicol. 1999, 19, 39-45.

97. Wiegel, N. L. Biochem. J. 1996, 319, 57-667.

98. Le Goff, P.; Montano, M. M.; Schodin, D. J.; Kastenellenbogen, B. S. J. Biol. Chem. 1994, 269, 44584466.

99. Miggliachio, A.; Rotondi, A.; Auricchio, F. EMBO J. 1986, 5, 2867-2872.

100. Arnold, S. F.; Obourn, J. D.; Jaffe, H.; Notides, A. C. Mol. Endocrinol. 1995, 9, 1041-1052.

101. Kato, S.; Endoh, H.; Masuhiro, Y.; Kitamoto, T.; Uchiyama, S.; Sasaki, H.; Masushige, S.; Gotoh, Y.; Nishida, E.; Kawashima, H.; Metzger, D.; Cambon, P. Science, 1995, 270, 1491-1494.

102. Arnold, S. F.; Obourn, J. D.; Yudt, M. R.; Carter, T. H.; Notides, A. C. J. Steroid Biochem. Mol. Biol. 1995, 52, 159171.

103. Chen, D.; Pace, P. E.; Coombes, C.; Ali, S. Mol. Cell. Biol. 1999, 19(2), 1002-1015.

104. Kuiper, G. G. J. M.; Enmark, E.; Peltohuikki, M.; Nilsson, S.; Gustaffson, J.-A. Proc. Natl. Acad. Sci. USA 1996, 93, 5925-5930.

105. Kuiper G. G. J. M.; Carlson, B.; Grandien, K.; Enmark, E.; Haggblad, J.; Nilsson, S.; Gustaffson, J-A. Endocrinology 1997, 138, 863-870.

106. Ogawa, S.; Inoue, S.; Watanabe, T.; Hiroi, H.; Orimo, A.; Hosoi, T.; Ouchi, Y.; Muramatsu, M. Biochem. Biophys. Res. Comm. 1998, 243, 122-126.

107. Chu, S.; Fuller, P. J. Mol. Cell. Endocrinol. 1997, 132, 195199.

108. Petersen, D. N.; Tkalcevic, G. T.; Koza-Taylor, P. H.; Turi, T. G.; Brown, T. A. Endocrinology 1998, 139 (3) 1082-1092.

109. Oesterreich, S.; Zhang, Q.; Hopp, T.; Fuqua, S. A.; Michaelis, M.; Zhao, H. H.; Davie, J. R.; Osborne, C. K.; Lee, A. V. Mol. Endocrinol. 2000, 14(3), 369-381

110. Gupta, S.; Upadhyay, R.; Kanungo, M. S. Mol Biol. Rep. 1998, 25 (4), 245-251.

111. Xing, H.; Shapiro, D. J. J. Biol. Chem. 1993, 268 (31), 23227-23233.

112. Eng, F. C.; Barsalou, A.; Akutsu, N.; Mercier, I.; Zechel, C.; Mader, S.; White, J. H. J. Biol. Chem. 1998, 273 (43), 2837128377.

113. Qin, C.; Singh, P.; Safe, S. Endocrinology, 1999, 140 (6), 2501-2508.

114. Batistuzzo de Medeiros, S. R.; Krey, G.; Hihi, A. K.; Wahli, W. J. Biol. Chem. 1997, 272(29), 18250-18260.

115. Chan, C. M.; Lykkesfeldt, A. E.; Parker, M. G.; Dowsett, M. Clin. Cancer Res. 1999, 5 (11), 3460-3467. 
116. Fraser, R. A.; Heard, D. J.; Adam, S.; Lavigne, A. C.; Le Douarin B.; Tora, L.; Losson, R.; Rochette-Egly, C.; Chambon, P. J. Biol. Chem. 1998. 273 (26), 16199-16204.

117. Riby, J. E.; Chang, G. H.; Firestone, G. L.; Bjeldanes, L. F. Biochem. Pharmacol. 2000 60(2), 167-77

118. Aronica, S. M.; Kastenellenbogen, B. S. Endocrinol. 1991, $128,2045-2052$.

119. Aronica, S. M.; Kastenellenbogen, B. S. Mol. Endocrinol. 1993, 7, 743-752

120. Smith, C. L.; Conneely, O. M.; O’Malley, B. W. Proc. Natl. Acad. Sci. USA 1993, 90, 6120-6124.

121. Ram, P. T.; Kiefer, T.; Silverman, M.; Song, Y.; Brown, G. M.; Hill, S. M. Mol. Cell. Endocrinol. 1998, 141, 53-64.

122. Shutt, D. A.; Cox, R. I. J. Encorinol. 1972, 37, 231-232

123. Verdeal, K.; Brown, R. R.; Richardson, T.; Ryan, D. S. J. N. C. I. 1980, 64 (2), 285 - 290.

124. Kuiper, G. G. J. M.; Lemmen, J. G.; Carlsson, B.; Corton, J. C.; Safe, S. H.; Van der Saag, P. T.; Van der Burg, B.; Gustafsson, J-A. Endocrinology 1998, 139, 4252-4263.

125. Pelissero, C.; Flouriot, G.; Foucher, J. L.; Bennetau, B.; Dunoguès, J.; Le Gac, F.; Sumpter, J. P. J. Steroid. Biochem. Molec. Biol. 1993, 44, 263-272.

126. Bennetau-Pelissero, C.; Flouriot, G.; Valotaire, Y.; Sumpter, J. P.; Le Menn, F. Ann. New York Acad. Sci. 1998, 839, 600-601.

127. Makela, S.; Davis, V. L.; Tally, W. C.; Korkman, J.; Salo, L.; Vihko, R.; Santti, R.; Korach, K. S. Environ. Health Perspect. 1994, 102(6-7), 572-578.

128. Henderson, B. E.; Ross, R. K.; Judd, H. L.; Krailo, M. D.; Pike, M. C. Cancer 1985, 56, 1206-1208.

129. Wu, A. H.; Ziegler, R. G.; Hornross, P. L.; Nomura, A. M. Y.; West, D. W.; Kolonel, L. N.; Rosenthal, J. F.; Hoover, R. N.; Pike, M. C. Cancer Epidemiol. Biomark. Prev. 1996, 5, 901-906.

130. Adlercreutz, H.; Hämälaïnen, E.; Gorbach, S.; Goldin, B. Lancet 1992, 339, 1233.

131. Morton, M. S.; Chan, P. S. F.; Cheng, C.; Blacklock, N.; Matos Ferreira, A.; Abranches Monteiro, L.; Correira, R.; Lloyd, S.; Griffiths, K. Prostate 1997, 32, 122-128.

132. Sumpter, J. P. Arch. Toxicol. Suppl. 1998, 20, 143-150.

133. Lichtenstein, A. H. J. Nutr. 1998, 128, 1589-1592.

134. Cassidy, A.; Bingham, S.; Setchell, K. D. R. Br. J. Nutr. 1995, 74, 587-560.

135. Cassidy, A.; Faughnan, M.; Huges, R.; Fraser, C.; Cathcart, A.; Taylor, N.; Setchell, K. D. R.; Bingham, S. Am. J. Clin. Nutr. 1998, 68, 1531S.

136. Hodgson, J. M.; Puddey, I. B.; Beilin, L. J.; Mori, T. A.; Croft, K. D. J. Nutr. 1998 128, 728-732.

137. Mitchell, J. H.; Collins, A. R. Eur. J. Nutr. 1999, 38, 143-148.

138. Anderson, J. W. ; Johnstone, B. M. ; Cook-Newell, M. E. N. Eng. J. Med. 1995, 333, 276-282.

139. Crouse, J. R.; Terry, J. G.; Morgan, T. M.; McGill, B. L.; Davis King, T.; Ellis, J. E.; Burke, G. L. Circulation 1998, 97, 816S.
140. György, P.; Murata, K.; Ikehata, H. Nature 1964, 203, 870872.

141. Figtree, G. A.; Griffiths, H.; Lu, Y. Q.; Webb, C. M.; MacLeod, K.; Collins, P. J. Am. Coll. Cardiol. 2000, 35(7), 1977-1985.

142. Pace Asciak, C. R.; Hahn, S.; Diamandis, E. P.; Soleas, G.; Goldberg, D. M. Clin. Chim. Acta. 1995, 235, 207-219.

143. Bingham, S. A.; Atkinson, C.; Liggins, J.; Bluck, L.; Coward, A. British J. Nutr. 1998, 79, 393-406.

144. Arjmandi, B. H.; Alekel, L.; Hollis, B. W.; Amin, D. J. Nutr. 1996, 126, 161-167.

145. Cooper, C.; Campion, G.; Melton, L. J. III. Osteoporos Int. 1992, 285-289.

146. Komm, B. S.; Tepening C. M.; Benz D. J.; Graeme, K. A.; Gallegos, A.; Korc, M.; Greene, G. L.; O'Malley, B. W.; Haussler, M. Science 1988, 241, 81-84.

147. Pansini, F.; Bonaccorsi, G.; Albertazzi P.; Costantino, D.; Valerio, A.; Negri, C.; Ferrazzini, S.; Bonocuore, I.; De Aloysio, D.; Fontana, A.; Pansini, N.; Mollica, G. In Proceedings of North American Menopause Society, p. 44.

148. Potter, S. M.; Baum, J. A.; Teng, H.; Stillman, R. J.; Shay, N. F.; Erdman, J. W. Am. J. Clin. Nutr. 1998, 68, 1375S1379S.

149. Adlercreutz, H.; Front. Gastrointest. Res. 1988, 14, 165-176.

150. Rose, D. P. Nutrition 1992, 8(1), 47-51.

151. Hawrylewicz, E. J.; Zapata, J. J.; Blair, W. H. J. Nutr. 1995, $125,698 \mathrm{~S}-708 \mathrm{~S}$.

152. Barnes, S.; Grubbs, C.; Setchell, K. D. R.; Carlson, J. In: Mutagens and Carcinogens in the diet; Wiley-Liss, Inc. 1990, pp 239-253.

153. Ingram, D.; Sanders, K.; Kolybaba, M.; Lopez, D. The Lancet 1997, 350, 990-994.

154. Constantinou, A. I.; Kamath, N.; Murley, J. S. Eur. J. Cancer 1998, 34(12), 1927-1934.

155. Mgbonyebi, O. P.; Russo, J.; Russo, I. H. Int. J. Oncol. 1998, $12,865-869$.

156. Fotsis, T.; Pepper, M.; Adlercreutz, H.; Hase, T.; Montesano, R.; Schweigerer, L. J. Nutr. 1995. 125, 790S-797S.

157. Adlercreutz, H.; Bannwart, C.; Wähälä, K.; Mäkelä, T.; Brunow, G.; Hase, T.; Arosemena, P. J.; Kellis, J. T. Jr; Vickery, L. E. J. Steroid Biochem. Molec. Biol. 1993, 44, 147-153.

158. Adlercreutz, H.; Hockerstedt, K.; Bannwart, C.; Bloigu, S.; Hämäläinen, E.; Fotsis, T.; Ollus, A. J. Steroid Biochem. 1987, 27(4-6), 1135-1144.

159. Thompson, L. U. Food Res. Inter. 1993, 26, 131-149.

160. Le Bail, J. C.; Varnat, F.; Nicolas, J. C.; Habrioux, G. Cancer Lett. 1998, 130(1-2), 209-216.

161. Welshons, W. V.; Murphy, C. S.; Koch, R.; Calaf, G.; Jordan, V. C. Breast Cancer Res. Treat. 1987, 10, 169-175.

162. Peterson, G.; Barnes, S. Biochem. Biophys. Comm. 1991, 179, 661-667.

163. Satyamoorthy, N.; Wang, T. T. Eur. J. Cancer 1997, 33(14), 2384-2389.

164. Zava, D. T.; Duwe, G. Nutr. Cancer 1997, 27(1), 31-40. 